\title{
In-vitro activity of sodium-hypochlorite gel on bacteria associated with periodontitis
}

Karolina Jurczyk • Sandor Nietzsche • Claudia Ender • Anton Sculean • Sigrun Eick

Karolina Jurczyk • Anton Sculean • Sigrun Eick $(\bowtie)$

Department of Periodontology, School of Dental Medicine, University of Bern, Freiburgstrasse

7, CH-3010 Bern, Switzerland

Karolina Jurczyk

Department of Conservative Dentistry and Periodontology, Poznan University of Medical Sciences, Poznan, Poland

Sandor Nietzsche $\bullet$ Claudia Ender

Center of Electron Microscopy, University Hospital Jena, Jena, Germany

\section{Corresponding author}

Sigrun Eick

University of Bern

School of Dental Medicine

Department of Periodontology; Laboratory of Oral Microbiology

Freiburgstrasse 7, 3010

Bern, Switzerland

Tel: + 41316322542

Fax: + 41316324915

Email: sigrun.eick@zmk.unibe.ch 
Objectives: The aim of the present study was to assess the antimicrobial activity of a sodium hypochlorite formulation incl. its components against bacteria associated with periodontal disease.

Materials and Methods: Sodium hypochlorite formulation ( $\mathrm{NaOCl}$ gel), its components sodium hypochlorite $(\mathrm{NaOCl})$ and the activating vehicle were compared with $0.1 \%$ chlorhexidine digluconate (CHX) solution. The antimicrobial activity was proven by determination of minimal inhibitory concentrations (MIC), minimal bactericidal concentrations, and killing assays. Furthermore, the influence on formation as well as on a 4-days old 6-species biofilm was tested.

Results: Except for one strain (Parvimonas micra ATCC 33270 in case of $\mathrm{NaOCl}$ gel) the MICs both of the $\mathrm{CHX}$ solution and $\mathrm{NaOCl}$ gel did not exceed $10 \%$ of the formulations' concentration. In general MICs of the $\mathrm{NaOCl}$ gel were equal as of the $\mathrm{CHX}$ solution against Gram-negatives but higher against Gram-positive bacteria. $\mathrm{CHX}$ but not $\mathrm{NaOCl}$ gel clearly inhibited biofilm formation, however the activity of $\mathrm{NaOCl}$ gel was more remarkable on a 4-d old biofilm. $\mathrm{NaOCl}$ killed bacteria in the biofilm and interfered with the matrix.

Conclusions: The NaOCl gel acts antimicrobial in particular against Gram-negative species associated with periodontitis. Moreover, its component $\mathrm{NaOCl}$ hypochlorite is able to alter biofilm matrices.

Clinical relevance: The $\mathrm{NaOCl}$ gel may represent a potential alternative for adjunctive topical antimicrobial treatment in periodontitis

Key words: sodium hypochlorite, periodontal infection, biofilm 


\section{Introduction}

Periodontitis is a chronic inflammatory disease of the tooth supporting tissues associated with high counts of certain bacterial species interacting with the host' immune system [1]. Oral microbial-plaque communities are biofilms composed of numerous bacteria on host surfaces. [2]. Bacteria more present in patients with chronic periodontitis than in periodontally healthy subjects are Treponema denticola, Porphyromonas gingivalis, Tannerella forsythia, and several others [3]. P. gingivalis a Gram-negative anaerobe bacterium, is considered a key-stone pathogen in developing periodontal disease [4].

Non-surgical mechanical removal of the hard and soft microbial deposits from the root surfaces (i.e. scaling and root planing (SRP)) is the standard in any cause-related periodontal therapy [5]. Substantial evidence indicates that during supportive periodontal therapy (SPT) periodontitis can be successfully treated and controlled by thorough mechanical plaque removal by the patient coupled with supra -and subgingival debridement by the therapist with or without the use of local antimicrobials [6]. During the last decade, various antimicrobials such as chlorhexidine, azithromycin, metronidazole, doxycycline, minocycline and tetracycline used subgingivally in conjunction with SRP have been tested [7]. Among the supragingivally used antiseptics, chlorhexidine based dentifrices/gels are still being the gold standard although tooth surface discoloration is observed as side effect [8].

An alternative approach to improve the outcomes of subgingival SRP might be the application of sodium hypochlorite. Its broad antimicrobial activity, fast bactericidal action and nontoxicity at application concentration, has been known since many years [9]. Already in 1918 it was published that sodium hypochlorite has a higher dissolving effect on necrotic tissue than on vital one [10]. However its use on everyday basis in dentistry is known basically in endodontics as one of the main canal irrigants [11]. Activity of sodium hypochlorite is depending on $\mathrm{pH}$. It is most active when applied at neutral or slightly acidic $\mathrm{pH}$ [12]. Comparison of the activity of different antiseptics on experimental biofilm with various endodontic/periodontal pathogens, showed that the highest bactericidal activity was obtained with $2.25 \%$ sodium hypochlorite and $10 \%$ povidone-iodine and last by $0.2 \%$ chlorhexidine [13]. Already in the early 80ies of the last century , the use of sodium hypochlorite combined with curretage was histologically shown to be effective in reducing soft tissue inflammation in SPT [14]. The results showed that sodium hypochlorite achieves predictable chemolysis of the soft tissue wall of the periodontal pocket with minimal effect on the adjacent tissues while the 
antiseptic did not impede the healing phase [14]. Moreover, it was suggested by Perova [15], that the use of $0.1 \%$ sodium hypochlorite during periodontal surgeries might improve the healing, through a markedly better regeneration of the connective tissue at the gingival base of the sites. Despite its promising properties, sodium hypochlorite did not stay in the light of interest for long, until it has been rediscovered just recently. An oral mouthrinse with $0.05 \%$ sodium hypochlorite resulted in significant reduction in supragingival biofilm accumulation and gingival inflammation [16]. In subsequent studies twice-weekly rinsing with $0.25 \%$ sodium hypochlorite solution decreased dental plaque level and reduced bleeding on probing in periodontal pockets $[17,18]$.

A formulation of a sodium hypochlorite gel to be used in periodontal therapy has been recently introduced to the market. It is composed of two components, sodium hypochlorite solution and a mixture of amino acids. After combining the two substrates different chloramines are synthesized from free sodium hypochlorite, which may additionally enhance the antimicrobial activity.

The purpose of this in vitro study was to determine the antimicrobial activity of the sodium hypochlorite gel and its components in comparison to chlorhexidine digluconate on microbial species associated with periodontitis including P. gingivalis, T. forsythia, Aggregatibacter actinomycetemcomitans, Parvimonas micra and others.

The hypothesis was that there is a minimal inhibitory concentration of sodium hypochlorite gel, which inhibits predictably the growth and biofilm formation of bacteria associated with periodontal disease.

\section{Material and methods}

\subsection{Substances}

Test substances were component 1 ( $\mathrm{NaOCl}$ : sodium hypochlorite solution $0.95 \%)$, component 2 (activating vehicle: glutamic acid, leucine, lysine, carboxymethyl cellulose, and ultrapure water) and sodium hypochlorite gel ( $\mathrm{NaOCl}$ gel (Perisolv, Regedent AG, Zurich, Switzerland)), composed of the previous two components mixed together. Chlorhexidine digluconate solution 
(CHX) in the concentration of $0.1 \%$ was used as a positive control, whereas $0.9 \%$ sodium chloride $(\mathrm{NaCl})$ as a negative control.

\subsection{Microorganisms}

The following bacterial strains were tested as single bacterial species: $P$. gingivalis ATCC 33277, T. forsythia ATCC 43037, Fusobacterium nucleatum ATCC 25586, Streptococcus gordonii ATCC 10558, Actinomyces naeslundii ATCC 12104, Parvimonas micra ATCC 33270, Prevotella intermedia ATCC 25611, A. actinomycetemcomitans ATCC 33384, Campylobacter rectus ATCC 33238, Eikenella corrodens ATCC 23834, Filifactor alocis ATCC 33099, Capnocytophaga gingivalis ATCC 33624, Eubacterium nodatum ATCC 33270 and three clinical isolates of $P$. gingivalis and $T$. forsythia. The mixed microbiota consisted of the following bacterial strains: P. gingivalis ATCC 33277, T. forsythia ATCC 43037, F. nucleatum ATCC 25586, S. gordonii ATCC 10558, A. naeslundii ATCC 12104 and P. micra ATCC 33270. Before an experiment, all strains were precultivated on Schaedler agar plates (Oxoid, Basingstoke, UK) with 5\% sheep blood and vitamin K addition, in an anaerobic atmosphere or with 5\% $\mathrm{CO}_{2}$ (A. actinomycetemcomitans ATCC 33384 and S. gordonii ATCC 10558).

\subsection{Susceptibility tests: Determination of the minimal inhibitory concentrations and minimal bactericidal concentrations}

Determination of MICs was performed by the micro-broth dilution technique using the 96-wellmicrotiter plates. The MICs of component 1 , component 2, Perisolv and $0.1 \%$ chlorhexidine solution for single microorganisms and mixed species were checked.

After subcultivation of bacterial strains, a defined inoculum, with an adjusted turbidity of McFarland 4 (0.5 for S. gordonii) was added to Wilkins Chalgren broth (Oxoid) supplemented with nicotinamide adenine dinucleotide and $\mathrm{N}$-acetyl muramic acid, in a 1:17 ratio. Defined concentrations of $\mathrm{NaOCl}$ gel, its components and chlorhexidine as positive control were added. 
After $42 \mathrm{~h}$ of incubation time (18 $\mathrm{h}$ for $S$. gordonii), the growth of microorganisms was analyzed visually by checking the turbidity. MIC represents the lowest concentration without visible turbidity of the broth.

For determination of the minimal bactericidal concentration, non-turbid cultures were subcultivated on agar plates without the addition of any antimicrobial agent. After incubating, the MBC was the lowest concentration without any growth of the colonies on the agar plates (equivalent to a reduction by $99.9 \%$ of the initial inoculum).

Tests were performed in independent replicates.

\subsection{Killing}

A defined inoculum of microorganisms (about $10^{6 /} \mathrm{ml}$ ), prepared in doubled concentrated nutrient media (Wilkins Chalgren broth), was added to $\mathrm{NaOCl}$ gel in final concentrations of $20 \%, 10 \%$ and $5 \%$, as well as $0.01 \%$ chlorhexidine. In this experiment the following bacterial species were used: P. gingivalis ATCC 3327, T. forsythia ATCC 43037, P. micra ATCC 33270 and the mixed species. After $1 \mathrm{~h}, 2 \mathrm{~h}, 6 \mathrm{~h}$ as well as $24 \mathrm{~h}$ of incubation, the numbers of viable bacteria were determined by enumeration of colony forming units (cfu). The test was performed in independent replicates.

\subsection{Activity against bacteria in biofilms}

In these experiments a multispecies biofilm consisting of $S$. gordonii ATCC 10558, $P$. gingivalis ATCC 33277, T. forsythia ATCC 43037, F. nucleatum ATCC 25586, A. naeslundii ATCC 12104 and P. micra ATCC 33270 was used. The influence of the test substances on the developing biofilm was examined. First the wells of 96-well-plates were covered with $20 \mu \mathrm{l}$ of test substance. After $1 \mathrm{~h}$ of incubation, $10 \mu \mathrm{l}$ of protein solution consisting of $25 \%$ serum and $5 \%$ albumin was added to the surface, followed by $170 \mu \mathrm{l}$ of bacterial suspension. Bacterial suspension was prepared by adding a defined inoculum (1 part S. gordonii, 2 parts A. naeslundii and each 4 parts of the other species; each McFarland 4) to Wilkins Chalgren broth (Oxoid) supplemented with nicotinamide adenine dinucleotide and $\mathrm{N}$-acetyl muramic acid, in a 1:17 
ratio. The 96-well-plates were incubated anaerobically at $37^{\circ}$ under static conditions. The cfu were counted after 6 h, $24 \mathrm{~h}$ and $48 \mathrm{~h}$ development of biofilm.

Additionally, the influence of the test substances was evaluated on a formed biofilm. Multispecies biofilm composed of six bacterial species was developed for four days. First the wells of 96-well-plates were covered with $10 \mu \mathrm{l}$ of 25\% v/v inactivated human serum/well for $1 \mathrm{~h}$. Then bacterial suspension was prepared and mixed with the Wilkins Chalgren broth as described above. The plates were incubated in the anaerobic atmosphere at $37^{\circ} \mathrm{C}$. After $48 \mathrm{~h}$ the medium was carefully exchanged with a new bacterial suspension of $P$. gingivalis ATCC 33277 and T. forsythia ATCC 43037 added to the nutrient medium before application to the wells. The renewed addition of selected bacterial strains guaranteed a sufficient number of these species within the biofilms.

After an additional incubation for $24 \mathrm{~h}$, the medium was removed carefully and $20 \mu \mathrm{l}$ of the tested substances were added to the biofilm. After 1 min, $180 \mu \mathrm{l}$ of Wilkins Chalgren broth was added and the plates were incubated for 18h. Finally, after short washing the biofilm was carefully scraped, mixed by pipetting and cfu were enumerated after serial dilutions, spreading of each $25 \mu \mathrm{l}$ on agar plates and incubation for $7 \mathrm{~d}$.

Half of the 96-well plate was used for staining of the biofilm with the Kwasny and Opperman method [19]. After a manual plate washing, the biofilm was fixed by incubating the washed plate at $60^{\circ} \mathrm{C}$ for $60 \mathrm{~min}$. Finally the staining was performed with $0.06 \%(\mathrm{w} / \mathrm{v})$ solution of crystal violet dissolved in $\mathrm{dH}_{2} \mathrm{O} .50 \mu \mathrm{l}$ of the above stain was used per well and left for 5 minutes. After the staining procedure, the excess was removed by repeated washing. The amount of crystal violet bounded in each well was directly measured spectrophotometrically by measuring $\mathrm{OD}_{600}$ using microplate reader.

These experiments were made in two independent experiments in independent sextuplicates.

In addition, 4-d old biofilm samples on glass slides, treated with the test substances and processed as described above were stained with $0.1 \%$ acridine orange solution (Merck, Darmstadt, Germany) as a general nucleic acid stain. Samples were examined by using fluorescent microscope (Olympus BX51, Tokyo, Japan).

Furthermore, scanning electron microscope photographs were taken to visualize the results. Exemplarily each test substance was chosen. Samples were fixed in $2 \%$ glutaraldehyde in 
cacodylate buffer for 30 min, washed twice with cacodylate buffer and dehydrated using a graded ethanol series (15 min each concentration). Following critical point drying, samples were sputter-coated with gold and examined with a ZEISS LEO-1530 Gemini (Carl Zeiss NTS $\mathrm{GmbH}$ ) equipped with a field emission electron gun at $8 \mathrm{keV}$.

\subsection{Statistical analysis}

All data are presented as mean and standard deviation (SD). Data were compared using a oneway analysis of variance (ANOVA) with post-hoc comparisons of groups using LSD corrections. A p-value of 0.05 was considered to be statistically significant. However, in case of $\log 10$ cfu values the cfu log10 reductions are of importance, following only log10 cfu values are presented. SPSS software (version 22.0) was used for statistical analysis.

\section{Results}

All results were related in \% to the working (commercially available) concentration ( $\mathrm{NaOCl}$ gel and $0.1 \%$ CHX respectively).

\subsection{Minimal inhibitory concentrations and minimal bactericidal concentrations}

Except for one strain (Parvimonas micra ATCC 33270 in case of NaOCl gel) the MICs both of the $\mathrm{CHX}$ solution and $\mathrm{NaOCl}$ gel did not exceed $10 \%$ of the formulations' concentration. In general MICs of $\mathrm{CHX}$ were lower than those of the $\mathrm{NaOCl}$ gel. However, when differentiating between Gram-positives and Gram-negatives the difference was mainly due to the Grampositive bacteria. NaOCl gel acted more growth inhibitory on Gram-negatives than on Grampositives. Mainly $\mathrm{NaOCl}$ was the active compound of $\mathrm{NaOCl}$ gel. But the activating vehicle exerted also some activity on Gram-negatives; here a synergistic effect can be stated when comparing $\mathrm{NaOCl}$ gel with its compounds (Figure 1).

The MBC values were in general equal or one step higher than the corresponding MIC values. The difference was more or equal 2 steps for CHX against two microorganisms (incl. the 
mixture) and for $\mathrm{NaOCl}$ gel against seven microorganisms (incl. the mixture). MBC values and individual MIC data are presented in Suppl. table 1.

\subsection{Killing curves}

Killing curves show the fast and total killing activity of $20 \%$ of the CHX solution and of the $\mathrm{NaOCl}$ gel. Only a few cells of $T$. forsythia were able to survive the exposure to the compounds. $\mathrm{NaOCl}$ gel was also tested in the lower concentrations of $5 \%$ and $10 \%$. In part, a concentration dependent activity was visible (Figure 2).

\subsection{Influence on formation of biofilm}

A clear inhibition of biofilm formation by CHX is shown. Up to $6 \mathrm{~h}$ no bacteria were cultivable; after 24 and 48 h, less than $0.5 \log 10$ cfu in mean were counted. The effect of NaOCl gel and its compounds was limited. The reduction was equally about $1.4 \log 10 \mathrm{cfu}$ in mean both for the $\mathrm{NaOCl}$ gel as for $\mathrm{NaOCl}$ and the activating vehicle. After $48 \mathrm{~h}$, the $\log 10$ cfu were the lower when the surface was coated with the activating vehicle (reduction about $2.7 \log 10$ cfu in mean) than with $\mathrm{NaOCl}$ gel (reduction about $0.6 \log 10 \mathrm{cfu}$ in mean) (Fig. 3).

\subsection{Influence on $4 \mathrm{~d}$ old biofilm}

In these assays, $100 \%$ of the formulations could act on the biofilms for 1 min before there was a dilution to $10 \%$.

The number of cultivable bacteria was reduced by about $6 \log 10 \mathrm{cfu}$ after application of NaOCl gel, being $1 \log 10$ cfu more than after $\mathrm{CHX}$. When $\mathrm{NaOCl}$ only was applied, no cultivable bacteria were detected. The activating vehicle itself did not have any effect (Fig 4A). These results did not correspond with those of the staining by cristal violet. Here, the highest values were measured for $\mathrm{NaOCl}$ ( $\mathrm{p}<0.01$ in comparison with control) followed by the untreated control and CHX. Lower staining was observed for the activating vehicle and the $\mathrm{NaOCl}$ gel $(p<0.05, p<0.01$ each in comparison with control) (Fig. 4B). 
Staining with acridine orange showed a diffuse staining of the biofilm control, after application of $\mathrm{CHX}$ and the activating vehicle. The staining is less diffuse after $\mathrm{NaOCl}$ gel, whereas after $\mathrm{NaOCl}$, only clear defined structures (bacteria) are stained (Fig. 5).

In all SEM photographs, many bacteria were visible. In part, damaged bacterial surfaces were detected after application of $\mathrm{NaOCl}$ and $\mathrm{NaOCl}$ gel. The matrix seemed to be less after $\mathrm{NaOCl}$ in comparison with the activating vehicle (Fig. 6).

\section{Discussion}

In this in vitro-study a sodium-hypochlorite gel was compared with a CHX solution which is still the gold standard in periodontal therapy. Growth inhibition and killing as well as the activity on a 6-species biofilm were evaluated.

MIC and MBC were determined by using standard procedures. The obtained values related to the available formulations revealed extremely low MICs of $\mathrm{CHX}$ and confirms findings from other studies [20, 21]. However, it should be mentioned that in the present study CHX was tested without any additives. It is well known that additives may influence disadvantageously the antimicrobial activity of commercial CHX formulations [22, 23]. The activity of $\mathrm{NaOCl}$ gel differed between Gram-positive and Gram-negative bacteria, growth of Gram-negatives is inhibited by lower concentrations. Interestingly, in the present study also the activating vehicle itself exerted certain antimicrobial activity. This selective inhibition may favor a more Grampositive microbiota with Actinomyces spp., oral streptococci being in general more associated with periodontal health [24]. Moreover, it should be noted, that Actinomyces spp. are able to reduce nitrate to nitrite [25]. Killing of those bacteria by broad-spectrum antiseptics disturbs the physiological role of these oral bacteria in blood pressure control [26].

One important question to be answered was whether the application of $\mathrm{NaOCl}$ gel on a surface after mechanical plaque removal may prevent biofilm formation. This property is well known for chlorhexidine [27, 28] which is in part linked to its high substantivity [29]. Our in vitro study confirms the inhibition of biofilm formation for $\mathrm{CHX}$, but for $\mathrm{NaOCl}$ gel no clear activity was seen. A slight inhibition ( $>1 \log 10 \mathrm{cfu}$ ) lasted only up to $24 \mathrm{~h}$. However, $\mathrm{NaOCl}$ gel and in particular its component $\mathrm{NaOCl}$ clearly reduced vitality of a 4-d old biofilm. The used mode 
simulated in vivo situation with an initial high (100\%) concentration of the compounds followed by a dilution.

The overwhelming activity of $\mathrm{NaOCl}$ on the 4-d old biofilm in relation to the action against planktonic bacteria suggests an interference with the biofilm matrix. Staining of the biofilm mass confirmed reduced values after $\mathrm{NaOCl}$ gel. Crystal violet binds to negatively charged cell surface molecules and extracellular polysaccharides as a component of the biofilm matrix [30, 31]. After $\mathrm{NaOCl}$ the values were higher, about this unexpected finding can only be speculated. One explanation might be the exposure of hidden cell molecules to the surface or it might be a non-specific effect caused by the alkaline $\mathrm{NaOCl}$.

Biofilm matrix consists of different components. Carbohydrates and proteins provide threedimensional architectural integrity [32], enzymatic cleavage of matrix components is discussed to effect biofilm dispersal. Moreover, extracellular DNA as an important component of biofilm matrices [33] is essential in stress relaxation of biofilms [34]. Its degradation represents also an interesting approach for biofilm control [35]. NaOCl removes proteins; this property is well described when applied to dentin in caries [36] or endodontic lesions [37]. Besides of proteins $\mathrm{NaOCl}$ may target extracellular DNA in biofilm matrix. It is very efficiently used in laboratories to decontaminate DNA [38]. In this study, staining with acridine orange was made. Acridine orange stains single-stranded and double-stranded DNA [39]. DNA staining of our biofilms may underline that extracellular DNA but not the intracellular bacterial DNA is destroyed by $\mathrm{NaOCl}$ [39]. Recently by using eDNA extraction it was shown that enzymatic treatment with DNase I was not able to affect biofilm matrix in a two-species biofilm model [40]. The results indicate $\mathrm{NaOCl}$ gel as an interesting approach in combating biofilm-associated diseases; further research should analyze its interference with biofilm matrix in more detail.

Both fluorescent staining as well as SEM photographs show bacteria also in the NaOCl treated biofilms. It can be suggested that bacteria are not viable anymore. In particular, a clear damage was also visible on coccoid species which might be of interest as $\mathrm{NaOCl}$ had high MIC values against both species included in the biofilm assays. On the other hand, the exposure of biofilms to antimicrobials may lead to formation of dormant persisters [41]. The presence of persisters cannot be excluded, since the time after exposure to high concentrations of antimicrobials might be too short to stimulate multiplication of persisters visible as cfu on agar plates.

Since several years, sodium hypochlorite gel has been proven to be effective in removal of dentin caries and despite the fact that treatment time was longer, the patients preferred this 
chemomechanical treatment to killing [42]. Furthermore, the data about its application in periodontal treatment are extremely rare and long-term studies are still missing. A study including 12 participants did not find any benefit in terms of decrease of instrumentation time, number of strokes to provide a calculus-free surface or subgingival calculus removal when sodium hypochlorite gel was applied adjunctive to SRP [43]. Similarly, the use of sodium hypochlorite gel as an adjunct to SRP presented no advantage for smear layer removal over scaling alone [44].

In summary, the present in-vitro study has shown that the new $\mathrm{NaOCl}$ gel acts antimicrobial in particular against Gram-negative species associated with periodontitis. Despite the fact that the $\mathrm{NaOCl}$ gel has failed to eliminate a multi-species biofilm, the vitality was clearly reduced and the matrix altered pointing to its high potential as an additive in mechanical therapy of periodontal disease.

Acknowledgements The authors would like to thank Anna Magdon and Stéphanie Larti (Department of Periodontology, Laboratory of Oral Microbiology, School of Dental Medicine, University of Bern) for technical assistance.

Compliance with Ethical Standards: This article does not contain any studies with human participants or animals performed by any of the authors.

Funding: This study was funded by by Regedent AG, Zurich, Switzerland.

Conflict of Interest: The authors declare that they have no conflict of interest.

\section{References}

1. Darveau RP (2010) Periodontitis: a polymicrobial disruption of host homeostasis. Nat Rev Microbiol 8:481-90

2. Teles R, Teles F, Frias-Lopez J, Paster B, Haffajee A (2013) Lessons learned and unlearned in periodontal microbiology. Periodontol 2000 62:95-162

3. Kumar PS, Griffen AL, Barton JA, Paster BJ, Moeschberger ML, Leys EJ (2003) New bacterial species associated with chronic periodontitis. J Dent Res 82:338-44

4. Hajishengallis G, Darveau RP, Curtis MA (2012) The keystone-pathogen hypothesis. Nat Rev Microbiol 10:717-25

5. Sanz I, Alonso B, Carasol M, Herrera D, Sanz M (2012) Nonsurgical treatment of periodontitis. J Evid Based Dent Pract 12:76-86

6. Hancock EB, Newell DH (2001) Preventive strategies and supportive treatment. Periodontol 2000 25:59-76 
7. Matesanz-Perez P, Garcia-Gargallo M, Figuero E, Bascones-Martinez A, Sanz M, Herrera D (2013) A systematic review on the effects of local antimicrobials as adjuncts to subgingival debridement, compared with subgingival debridement alone, in the treatment of chronic periodontitis. J Clin Periodontol 40:227-41

8. Slot DE, Berchier CE, Addy M, Van der Velden U, Van der Weijden GA (2014) The efficacy of chlorhexidine dentifrice or gel on plaque, clinical parameters of gingival inflammation and tooth discoloration: a systematic review. Int J Dent Hyg 12:25-35

9. Slots J (2002) Selection of antimicrobial agents in periodontal therapy. J Periodontal Res 37:389-98

10. Austin JH, Taylor HD (1918) Behavior of hypochlorite and of chloramine-T Solutions in contact with necrotic and normal tissues in vivo. J Exp Med 27:627-33

11. Mohammadi Z (2008) Sodium hypochlorite in endodontics: an update review. Int Dent J 58:329-41

12. Del Carpio-Perochena A, Bramante CM, de Andrade FB, Maliza AG, Cavenago BC, Marciano MA, Amoroso-Silva P, Duarte MH (2015) Antibacterial and dissolution ability of sodium hypochlorite in different pHs on multi-species biofilms. Clin Oral Investig

13. Spratt DA, Pratten J, Wilson M, Gulabivala K (2001) An in vitro evaluation of the antimicrobial efficacy of irrigants on biofilms of root canal isolates. Int Endod J 34:300-7

14. Kalkwarf KL, Tussing GJ, Davis MJ (1982) Histologic evaluation of gingival curettage facilitated by sodium hypochlorite solution. J Periodontol 53:63-70

15. Perova MD, Lopunova Zh K, Banchenko GV, Petrosian EA (1990) [A clinico-morphological assessment of the efficacy of sodium hypochlorite in the combined therapy of periodontitis]. Stomatologiia (Mosk) 69:23-6

16. De Nardo R, Chiappe V, Gomez M, Romanelli H, Slots J (2012) Effects of 0.05\% sodium hypochlorite oral rinse on supragingival biofilm and gingival inflammation. Int Dent J 62:20812

17. Gonzalez S, Cohen CL, Galvan M, Alonaizan FA, Rich SK, Slots J (2015) Gingival bleeding on probing: relationship to change in periodontal pocket depth and effect of sodium hypochlorite oral rinse. J Periodontal Res 50:397-402

18. Galvan M, Gonzalez S, Cohen CL, Alonaizan FA, Chen CT, Rich SK, Slots J (2014) Periodontal effects of $0.25 \%$ sodium hypochlorite twice-weekly oral rinse. A pilot study. J Periodontal Res 49:696-702

19. Kwasny SM, Opperman TJ (2010) Static biofilm cultures of Gram-positive pathogens grown in a microtiter format used for anti-biofilm drug discovery. Curr Protoc Pharmacol Chapter 13:Unit 13A 8

20. do Amorim CV, Aun CE, Mayer MP (2004) Susceptibility of some oral microorganisms to chlorhexidine and paramonochlorophenol. Braz Oral Res 18:242-6

21. Eick S, Radakovic S, Pfister W, Nietzsche S, Sculean A (2012) Efficacy of taurolidine against periodontopathic species--an in vitro study. Clin Oral Investig 16:735-44

22. Eick S, Goltz S, Nietzsche S, Jentsch H, Pfister W (2011) Efficacy of chlorhexidine digluconatecontaining formulations and other mouthrinses against periodontopathogenic microorganisms. Quintessence Int 42:687-700

23. Li W, Wang RE, Finger M, Lang NP (2014) Evaluation of the antigingivitis effect of a chlorhexidine mouthwash with or without an antidiscoloration system compared to placebo during experimental gingivitis. J Investig Clin Dent 5:15-22

24. Colombo AP, Boches SK, Cotton SL, Goodson JM, Kent R, Haffajee AD, Socransky SS, Hasturk H, Van Dyke TE, Dewhirst F, Paster BJ (2009) Comparisons of subgingival microbial profiles of refractory periodontitis, severe periodontitis, and periodontal health using the human oral microbe identification microarray. J Periodontol 80:1421-32

25. Doel JJ, Benjamin N, Hector MP, Rogers M, Allaker RP (2005) Evaluation of bacterial nitrate reduction in the human oral cavity. Eur J Oral Sci 113:14-9

26. Kapil V, Haydar SM, Pearl V, Lundberg JO, Weitzberg E, Ahluwalia A (2013) Physiological role for nitrate-reducing oral bacteria in blood pressure control. Free Radic Biol Med 55:93-100

27. Takeuchi Y, Guggenheim B, Filieri A, Baehni P (2007) Effect of chlorhexidine/thymol and fluoride varnishes on dental biofilm formation in vitro. Eur J Oral Sci 115:468-72 
28. Singh A, Daing A, Dixit J (2013) The effect of herbal, essential oil and chlorhexidine mouthrinse on de novo plaque formation. Int J Dent Hyg 11:48-52

29. Baker PJ, Coburn RA, Genco RJ, Evans RT (1978) The in vitro inhibition of microbial growth and plaque formation by surfactant drugs. J Periodontal Res 13:474-85

30. Vandecandelaere I, Van Acker H, Coenye T (2016) A Microplate-Based System as In Vitro Model of Biofilm Growth and Quantification. Methods Mol Biol 1333:53-66

31. Peeters E, Nelis HJ, Coenye T (2008) Comparison of multiple methods for quantification of microbial biofilms grown in microtiter plates. J Microbiol Methods 72:157-65

32. Hobley L, Harkins C, MacPhee CE, Stanley-Wall NR (2015) Giving structure to the biofilm matrix: an overview of individual strategies and emerging common themes. FEMS Microbiol Rev 39:649-69

33. Okshevsky M, Meyer RL (2013) The role of extracellular DNA in the establishment, maintenance and perpetuation of bacterial biofilms. Crit Rev Microbiol

34. Peterson BW, van der Mei HC, Sjollema J, Busscher HJ, Sharma PK (2013) A distinguishable role of eDNA in the viscoelastic relaxation of biofilms. MBio 4:e00497-13

35. Okshevsky M, Regina VR, Meyer RL (2015) Extracellular DNA as a target for biofilm control. Curr Opin Biotechnol 33:73-80

36. Gomez S, Bravo P, Morales R, Romero A, Oyarzun A (2014) Resin penetration in artificial enamel carious lesions after using sodium hypochlorite as a deproteinization agent. J Clin Pediatr Dent 39:51-6

37. Zhang K, Kim YK, Cadenaro M, Bryan TE, Sidow SJ, Loushine RJ, Ling JQ, Pashley DH, Tay FR (2010) Effects of different exposure times and concentrations of sodium hypochlorite/ethylenediaminetetraacetic acid on the structural integrity of mineralized dentin. $\mathrm{J}$ Endod 36:105-9

38. Prince AM, Andrus L (1992) PCR: how to kill unwanted DNA. Biotechniques 12:358-60

39. Darzynkiewicz Z, Juan G, Srour EF (2004) Differential staining of DNA and RNA. Curr Protoc Cytom Chapter 7:Unit 73

40. Ali Mohammed MM, Nerland AH, Al-Haroni M, Bakken V (2013) Characterization of extracellular polymeric matrix, and treatment of Fusobacterium nucleatum and Porphyromonas gingivalis biofilms with DNase I and proteinase K. J Oral Microbiol 5:

41. Lewis K (2010) Persister cells. Annu Rev Microbiol 64:357-72

42. Fure S, Lingstrom P (2004) Evaluation of the chemomechanical removal of dentine caries in vivo with a new modified Carisolv gel. Clin Oral Investig 8:139-44

43. Grisi DC, Salvador SL, Marcantonio RA (2006) Efficacy of Carisolv as an adjunctive therapy to scaling and root planing on subgingival calculus removal. Braz Dent J 17:213-8

44. Imbronito AV, Okuda O, Del Cioppo CV, Arana-Chavez VE (2011) Scanning electron microscopy in vitro study on the effect of Carisolv application on periodontally diseased root surfaces. Int J Periodontics Restorative Dent 31:91-5

Figure legends

Figure 1

MIC values of $\mathrm{NaOCl}$ gel incl. its components and chlorhexidine digluconate (related to the used formulations) against all species, Gram-positives and Gram-negatives

Figure 2 
Killing of Porphyromonas gingivalis ATCC 33277, Tannerella forsythia ATCC 43037, Parvimonas micra ATCC 33270 and a 6-species mixture by different concentrations of $\mathrm{NaOCl}$ gel and $0.02 \%$ chlorhexidine digluconate (equivalent to $20 \%$ of a $0.1 \%$ formulation)

Figure 3

Influence of $\mathrm{NaOCl}$ gel incl. its components and $0.1 \%$ chlorhexidine digluconate on formation of a 6-species biofilm.

Surfaces were coated with test substances for $1 \mathrm{~h}$ before bacterial suspensions were added.

Figure 4

Influence of $\mathrm{NaOCl}$ gel incl. its components and $0.1 \%$ chlorhexidine digluconate on 4 days old 6-species biofilm.

$\mathrm{NaOCl}$ gel incl. its components and $0.1 \%$ chlorhexidine digluconate were added for $1 \mathrm{~h}$ to the biofilm, thereafter they were diluted 1: 9 for $18 \mathrm{~h}$, before cfu (A) were determined and matrix was stained by cristal violet (B)

Figure 5

Staining of DNA in a $4 \mathrm{~d}$ old biofilm without (A) and after addition of $0.1 \%$ chlorhexidine digluconate (B), $\mathrm{NaOCl}$ gel (C) and its components $\mathrm{NaOCl}(\mathrm{D})$ and activating vehicle (E) for 1 $\mathrm{h}$ and after dilution 1: 9 for $18 \mathrm{~h}$

Figure 6

Scanning electron microscopy photographs of a $4 \mathrm{~d}$ old biofilm without (A) and after addition of $0.1 \%$ chlorhexidine digluconate (B), $\mathrm{NaOCl}$ gel (C, D) and its components $\mathrm{NaOCl}(\mathrm{E})$ and activating vehicle (F) for $1 \mathrm{~h}$ and after dilution 1: 9 for $18 \mathrm{~h}$ 

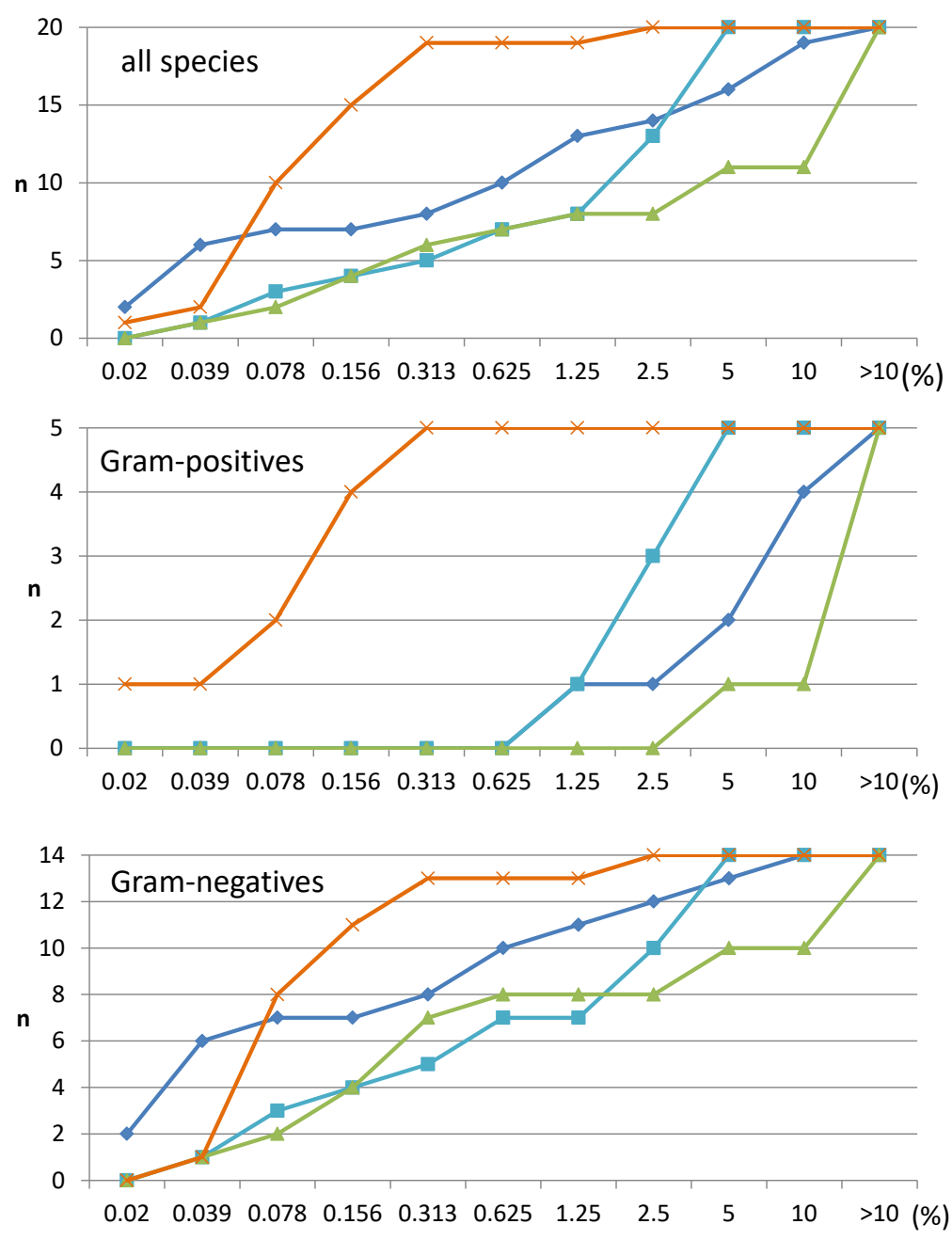

$\smile \mathrm{NaOCl}$ gel $\_-\mathrm{NaOCl} \_$vehicle $\leftarrow \mathrm{CHX}$ (related to $0.1 \%$ )

Figure 1 

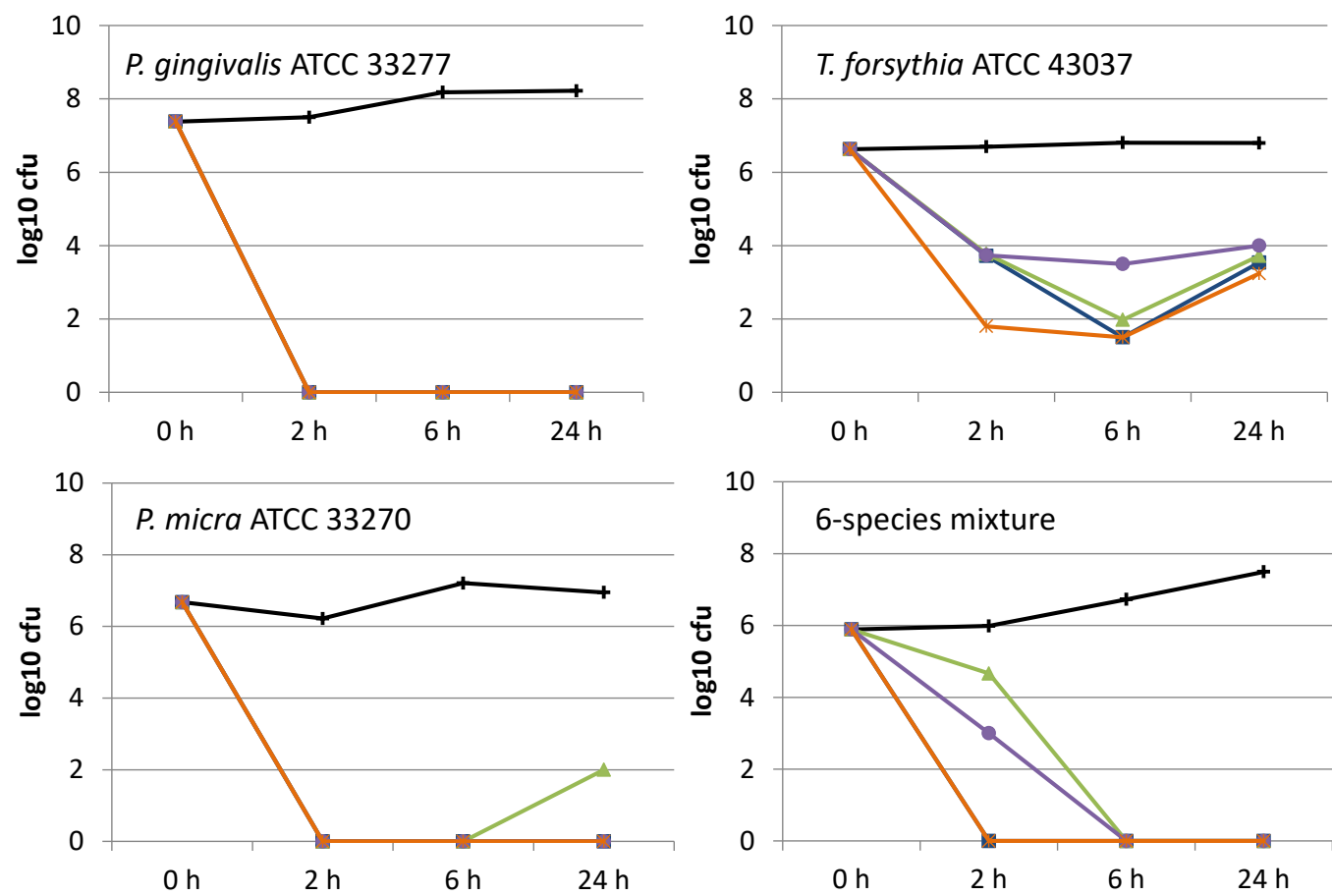

+ con $\rightarrow \mathrm{NaOCl}$ gel $20 \% \rightarrow \mathrm{NaOCl}$ gel $10 \% \rightarrow-\mathrm{NaOCl}$ gel $5 \% \quad * \mathrm{CHX} 0.02 \%$

Figure 2 


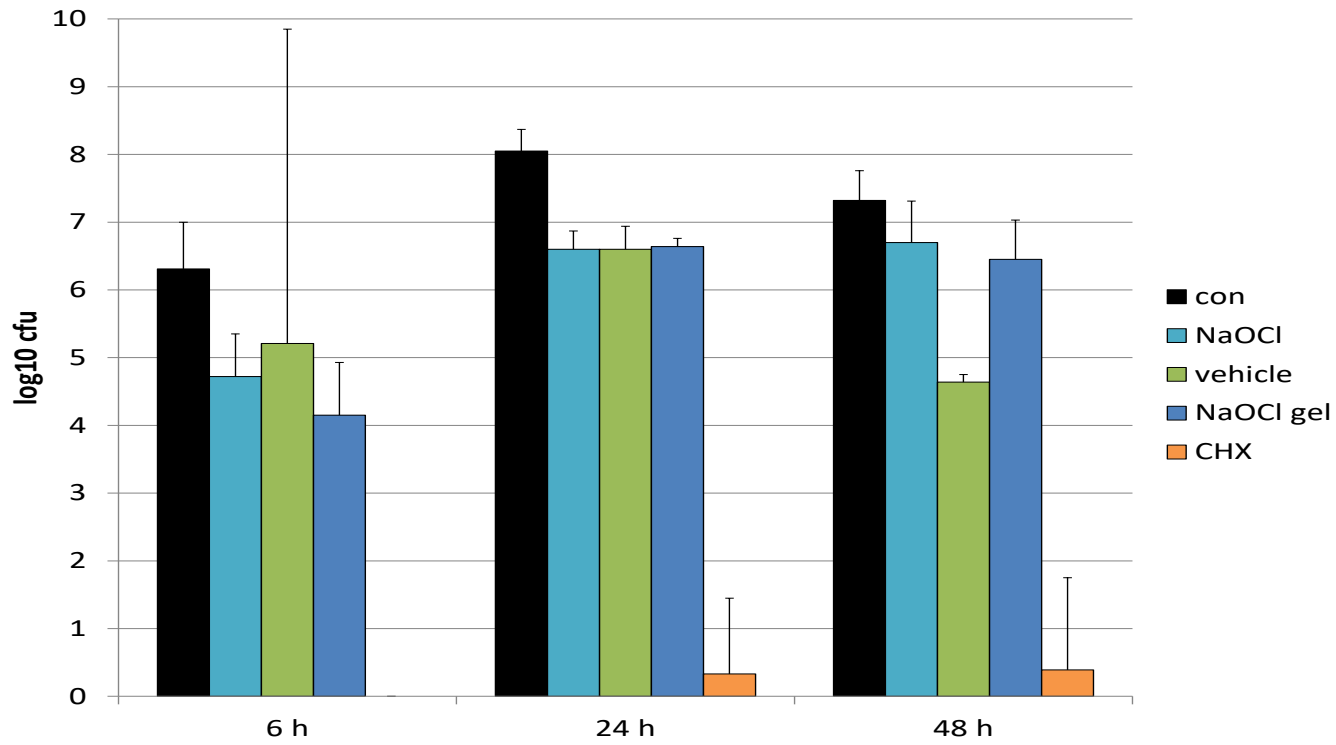

Figure 3 

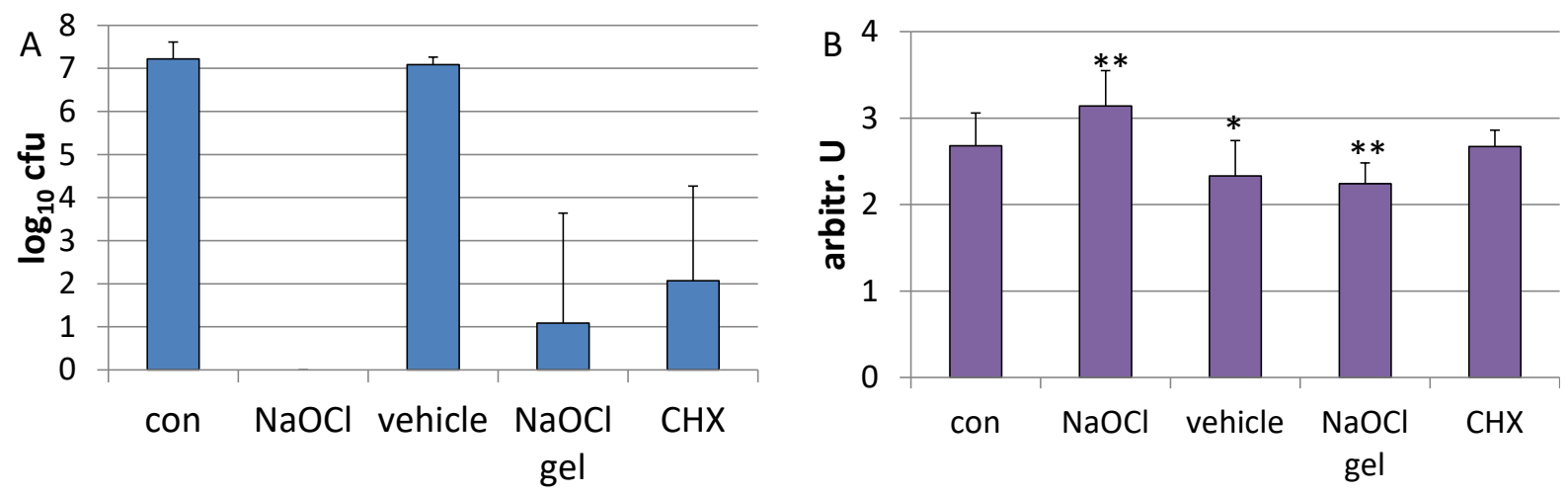

Figure 4
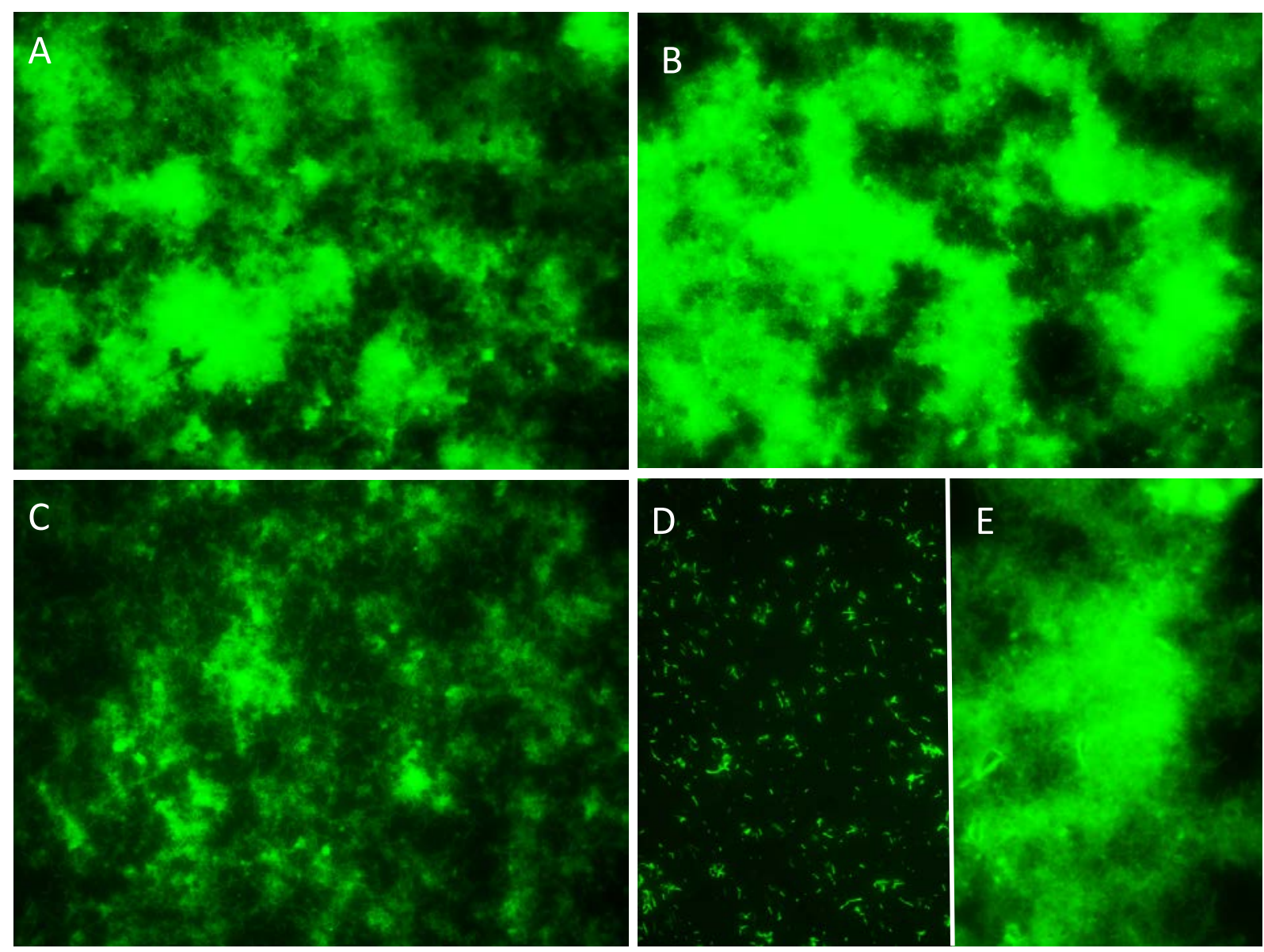

Figure 5 

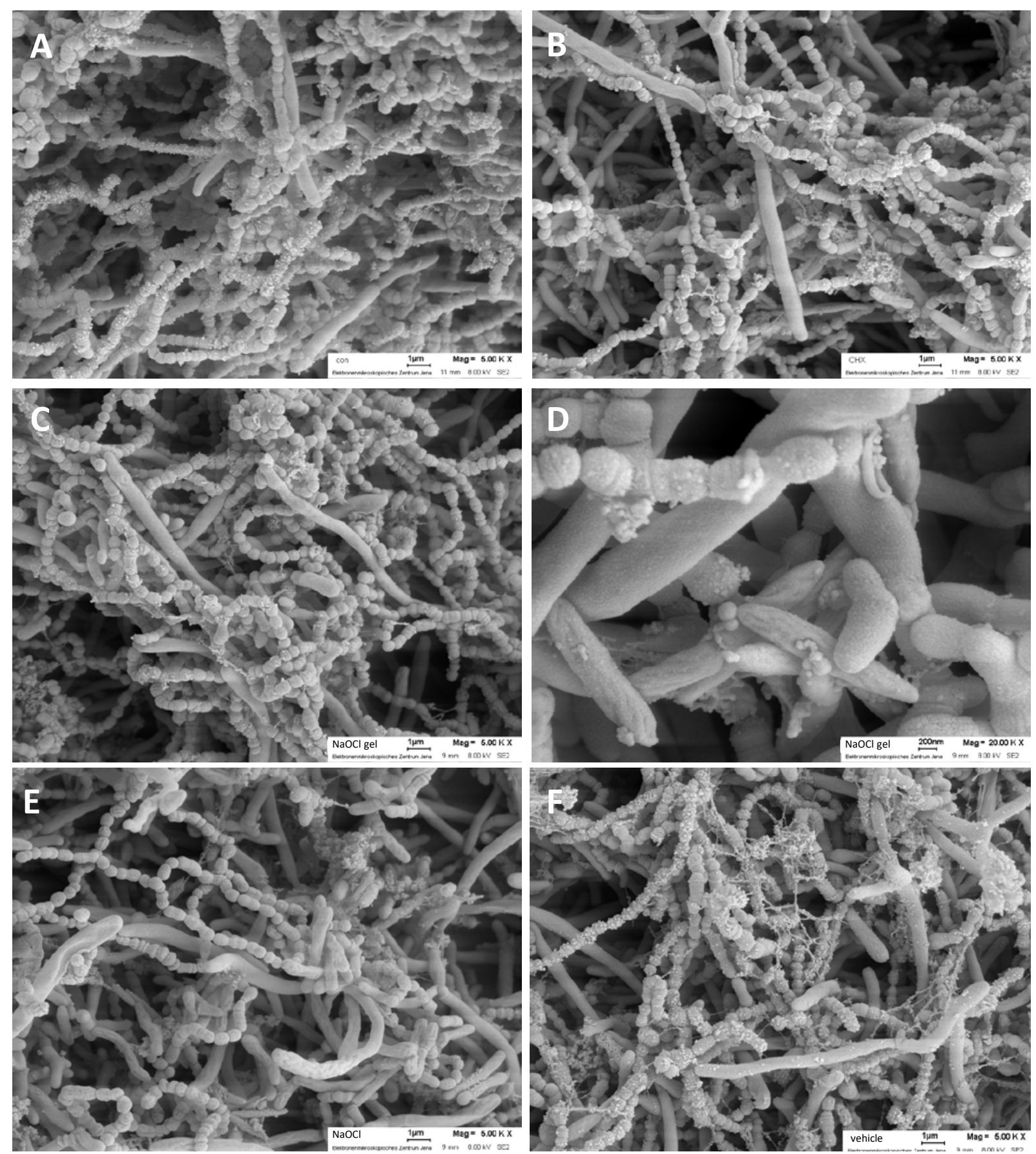

Figure 6 
Suppl. Table 1

MIC and MBC values of $\mathrm{NaOCl}$ gel and chlorhexidine digluconate against studied bacterial strains and the 6-species mixtures (values are given in $\%$ of the available formulation ( $\mathrm{NaOCl}$ gel and $0.1 \%$ chlorhexidine digluconate)

\begin{tabular}{|c|c|c|c|c|c|c|c|c|}
\hline & \multicolumn{3}{|c|}{$\begin{array}{l}\text { MIC of NaOCl gel and its } \\
\text { components }\end{array}$} & \multirow{2}{*}{$\begin{array}{l}\text { MIC of } \\
\text { chlorhexidine } \\
\text { digluconate }\end{array}$} & \multicolumn{3}{|c|}{$\begin{array}{l}\text { MBC of NaOCl gel and its } \\
\text { components }\end{array}$} & \multirow{2}{*}{\begin{tabular}{|l|} 
MBC of \\
chlorhexidine \\
digluconate
\end{tabular}} \\
\hline & NaOCI gel & NaOCl & Vehicle & & NaOCl gel & NaOCl & $\begin{array}{l}\text { Activating } \\
\text { vehicle }\end{array}$ & \\
\hline $\begin{array}{l}\text { Porphyromonas } \\
\text { gingivalis ATCC } 33277\end{array}$ & 0.625 & 2.500 & 0.156 & 0.156 & 0.625 & 2.500 & 0.625 & 0.313 \\
\hline P. gingivalis J430 & 0.039 & 0.039 & 0.078 & 0.078 & 0.078 & 0.078 & 0.156 & 0.078 \\
\hline P. gingivalis ORA & 0.039 & 0.313 & 0.312 & 0.078 & 0.156 & 0.625 & 2.500 & 0.156 \\
\hline P. gingivalis M5-1-2 & 0.039 & 0.625 & 0.156 & 0.078 & 0.078 & 1.250 & 0.313 & 0.156 \\
\hline $\begin{array}{l}\text { Tannerella forsythia } \\
\text { ATCC } 43037\end{array}$ & 0.020 & 0.156 & 0.312 & 0.078 & 0.039 & 0.156 & 0.312 & 0.156 \\
\hline T. forsythia B13216 & 0.020 & 0.078 & 0.039 & 0.078 & 0.078 & 0.156 & 0.156 & 0.078 \\
\hline T. forsythia RA12 & 0.039 & 0.039 & 0.156 & 0.039 & 0.078 & 0.078 & 0.156 & 0.039 \\
\hline T. forsythia $\mathrm{O} 20$ & 0.078 & 0.313 & 0.313 & 0.078 & 0.156 & 0.625 & 0.313 & 0.078 \\
\hline $\begin{array}{l}\text { Fusobacterium } \\
\text { nucleatum ATCC } 25586\end{array}$ & 1.250 & 5.000 & $>10.000$ & 0.156 & 5.000 & 5.000 & $>10.000$ & 0.156 \\
\hline $\begin{array}{l}\text { Streptococcus gordonii } \\
\text { ATCC } 10558\end{array}$ & 10.000 & 5.000 & $>10.000$ & 0.078 & 10.000 & 2.500 & $>10.000$ & 0.156 \\
\hline $\begin{array}{l}\text { Actinomyces naeslundii } \\
\text { ATCC } 12104\end{array}$ & 10.000 & 1.250 & $>10.000$ & 0.156 & 10.000 & 2.500 & $>10.000$ & 0.156 \\
\hline $\begin{array}{l}\text { Parvimonas micra } \\
\text { ATCC } 33270\end{array}$ & $>10.000$ & 2.500 & $>10.000$ & 0.313 & $>10.000$ & 2.500 & $>10.000$ & 0.625 \\
\hline $\begin{array}{l}\text { Prevotella intermedia } \\
\text { ATCC } 25611\end{array}$ & 0.313 & 5.000 & 5.000 & 0.156 & 0.313 & 5.000 & 10.000 & 0.313 \\
\hline
\end{tabular}




\begin{tabular}{|l|c|c|c|c|c|c|c|c|}
\hline $\begin{array}{l}\text { Aggregatibacter } \\
\text { actinomycetemcomitans } \\
\text { ATCC 33384 }\end{array}$ & 10.000 & 5.000 & $>10.000$ & 0.313 & 10.000 & 10.000 & $>10.000$ & 0.625 \\
\hline $\begin{array}{l}\text { Campylobacter rectus } \\
\text { ATCC 33238 }\end{array}$ & 0.625 & 2.500 & $>10.000$ & 0.078 & 5.000 & 1.250 & $>10.000$ & 0.078 \\
\hline $\begin{array}{l}\text { Eikenella corrodens } \\
\text { ATCC 23834 }\end{array}$ & 2.500 & 5.000 & $>10.000$ & 2.500 & 5.000 & 5.000 & $>10.000$ & 5.000 \\
\hline $\begin{array}{l}\text { Filifactor alocis ATCC } \\
\text { 33099 }\end{array}$ & 1.250 & 2.500 & $>10.000$ & 0.156 & 5.000 & 5.000 & $>10.000$ & 0.156 \\
\hline $\begin{array}{l}\text { Capnocytophaga } \\
\text { gingivalis ATCC 33624 }\end{array}$ & 5.000 & 2.500 & 5.000 & 0.313 & 5.000 & 5.000 & $>10.000$ & 0.625 \\
\hline $\begin{array}{l}\text { Eubacterium nodatum } \\
\text { ATCC 33270 }\end{array}$ & 5.000 & 5.000 & 5.000 & 0.020 & $>10.000$ & 5.000 & $>10.000$ & 0.156 \\
\hline 6-species mixture & 1.250 & 5.000 & $>10.000$ & 0.313 & 10.000 & 5.000 & $>10.000$ & 1.250 \\
\hline
\end{tabular}

